\title{
Perlindungan Hukum Terhadap Anak Korban Kejahatan Seksual dalam Perspektif Hukum Progresif
}

\author{
Naskah Masuk: 11 Maret 2016 // Naskah Diterima: 13 Mei 2016 \\ DOI: 10.18196/jmh.2015.0066.37-47
}

\begin{abstract}
A child has the right in the same as like own adult people. There are not many people that have thought to do certain things with Children's right protection. So there are some efforts to protect children's right that have been broken by country, adult, their environment, or their parents that did not give much attention to their future. Whereas, child as the soul and the reflection of the future, family asset, religion, and nation. Child get bad experience, like children exploitation, children abusement, being sex toy, child labor, abandoned, become the street children, victims of drug trafficking. Universally, Indonesia in breaking of the children's right in real or nonreal become a normal and common image as mass media gives news about that. Indonesia as a law nation based on Pancasila must give a law protection to society, because of that the law protection will produce confession and human rights protection in his shape as individual creatures and social creatures in a unitary state that uphold family spirit in order to attain public welfare. Law enforcement to child victims of sexual crime in North Sumatraas conceptually has been located on the harmonizing relations of the values which span the hierarchy activities in good rules and with attitude as series value hierarchy, to build, maintain, and defend the peacefulness social life, conception that has basic philosophy that makes more solid. Construction law to protection children victims of sexual crime in progrsive law perspective is an ideology and dedication of the perpetrators of law got the first place to do a dignification. Key Words: Law Protection, Crime Victims, Progressives Law
\end{abstract}

\begin{abstract}
ABSTRAK
Anak mempunyai hak asasi, sebagaimana yang dimiliki orang dewasa, perlindungan hak anak tidak banyak pihak yang turut memikirkan dan melakukan langkah-langkah konkrit. Demikian juga upaya untuk melindungi hak-hak anak yang dilanggar yang dilakukan oleh Negara, orang dewasa, lingkungan sendiri atau orang tuanya yang tidak begitu menaruh perhatian akan kepentingan masa depan anak. Padahal anak merupakan belahan jiwa, gambaran dan cermin masa depan, aset keluarga, agama, bangsa dan Negara. Indonesia sebagai Negara hukum berdasarkan Pancasila haruslah memberikan perlindungan hukum terhadap warga masyarakatnya karena perlindungan hukum akan melahirkan pengakuan dan perlindungan hak asasi manusia dalam wujudnya sebagai makhluk individu dan makhluk sosial dalam wadah Negara kesatuan yang menjunjung tinggi semangat kekeluargaan demi tercapainya kesejahteraan masyarakat. Penegakan hukum terhadap anak korban kejahatan seksual di Propinsi Sumatera Utara Secara konsepsional terletak pada kegiatan menyerasikan hubungan nilai-nilai yang terjabarkan dalam kaidah yang bagus pada sikap tindak sebagai rangkaian penjabaran nilai, untuk menciptakan, memelihara dan mempertahankan kedamaian pergaulan hidup, konsepsi yang mempunyai dasar filosofis sehingga akan tampak lebih konkret. Pembangunan hukum terhadap perlindungan anak korban kejahatan seksual dalam perspektif hukum progresif adalah berupa ideologi dan dedikasi para pelaku hukum mendapat tempat yang utama untuk melakukan pemulihan.
\end{abstract}

Kata Kunci: Perlindungan Hukum, Anak Korban Kejahatan, Hukum Progresif 


\section{PENDAHULUAN}

Setiap anak mempunyai hak asasi, sebagaimana hak yang dimiliki oleh orang dewasa, tidak banyak pihak yang turut memikirkan dan mau melakukan langkahlangkah konkret untuk melindungi hak anak. Anak merupakan individu yang belum matang baik secara fisik, maupun mental apalagi sosialnya. Sehingga jika dibandingkan dengan orang dewasa, jelas anak akan lebih beresiko terhadap kekerasan dan penelantaran. Secara garis besar, dampak kekerasan terhadap anak antara lain:

a. Anak menjadi negatif dan agresif serta mudah frustasi.

b. Menjadi sangat pasif dan apatis.

c. Tidak mempunyai kepribadian sendiri, apa yang dilakukan sepanjang hidupnya hanyalah memenuhi keinginan orangtuanya.

d. Rendah diri

e. Sulit menjalin relasi dengan individu lain. Perbuatan kejahatan seksual selalu terkait dengan perbuatan tubuh atau bagian tubuh terutama pada bagian-bagian yang dapat merangsang nafsu seksual (Sugandhi, 1981: 309). Kehadiran hukum progresif bukanlah sesuatu yang lahir tanpa penyebab, hukum progresif terlahir karena bagian dari proses pencarian keadilan dan kebenaran (searching for the truth) yang tidak dapat, tidak pernah berhenti. Hal ini dipertegas lagi dengan pandangan Satjipto Rahardjo (Rahardjo, 2006: 3), bahwa hukum progresif dapat dipandang sebagai konsep yang mencari jati diri, bertolak dengan realitas empirik tentang bekerjanya hukum ditengah masyarakat berupa ketidak puasan terhadap kineja dalam kualitas penegak hukum.

Berdasarkan latar belakang masalah di atas, maka dalam penelitian ini dirumuskan masalah sebagai berikut: (1) Bagaimana konsep perlindungan hukum terhadap anak korban kejahatan seksual menurut hukum positif? (2)
Bagaimana penegakan hukum terhadap anak korban kejahatan seksual di Sumatera Utara? (3) Bagaimana pembangunan hukum terhadap perlindungan anak korban kejahatan seksual dalam perspektif hukum progresif?

\section{METODE PENELITIAN}

A. Pendekatan dan Sifat Penelitian

Metode pendekatan Normatif, hukum di identifikasikan sebagai norma peraturan atau Undang-Undang (UU). Sedangkan sifat penelitiannya deskriptif untuk melihat hukum dalam arti nyata, dan meneliti bagaimana bekerjanya hukum di lingkungan masyarakat (Ali, 2012: 72).

B. Jenis dan Sumber Data Penelitian Penelitian ini menggunakan jenis penelitian kepustakaan. Dengan memakai bahan-bahan hukum, sebagai upaya untuk menghasilkan argumentasi, teori dan konsep baru sebagai preskripsi dalam menyelesaikan masalah yang dihadapi. Sumber data dalam penelitian dengan memakai bahan hukum Primer, dan bahan Hukum Sekunder. ini akan meneliti efektivitas suatu undang-undang.

C. Pengolahan dan Analisis Data

Pengelolahan dan analisis data yang digunakan dalam penelitian ini menggunakan metode kualitatif, dengan cara memadukan antara penelitian kepustakaan dan penelitian lapangan. Serta membandingkan peraturan-peraturan, ketentuan-ketentuan tentang penggunaan hukum progresif terhadap perlindungan anak korban kejahatan seksual dalam hukum progresif.

\section{HASIL PENELITIAN DAN ANALISIS \\ A. KAJIAN TENTANG KEJAHATAN}

Di dalam diri manusia selalu ada kemauan untuk hidup yang menjadi sumber bagi potensipotensi kreativitas. Namun seiring dengan hal itu, pada diri manusia juga selalu ada kemauan 
untuk berkuasa yang menjadi sumber berbagai tindakan destruksi manusia. Dikatakan destruksi, karena kemauan untuk berkuasa tidak pernah mengenal kata akhir, tidak pernah mengenal batas, tidak pernah mengenal kata cukup. Konflik-konflik manusia yang mengakibatkan banyaknya malapetaka adalah konflik-konflik antara kemauan untuk berkuasa dengan kemauan untuk berkuasa lainnya (Simanjuntak, 1981: 44). Akibat yang ditimbulkan menjadi tolak ukur suatu kejahatan, apakah modus kejahatan itu berkategori ringan ataukah pemberatan dan mengakibatkan penderitaan luar biasa. Secara yuridis formal, kejahatan adalah semua perbuatan manusia yang memenuhi perumusan ketentuan hukum pidana secara definitif yang dinyatakan sebagai perbuatan kejahatan (Utrecht, 1986: 253). Hal ini dipertegas lagi oleh Wirjono Prodjodikoro bahwa tindak pidana berarti suatu perbuatan yang pelakunya dapat dikenai hukuman pidana (Wirjono Prodjodikoro, 2003: 59). Dilihat dari sudut formil, kejahatan adalah suatu perbuatan yang oleh masyarakat (dalam hal ini negara) diberi pidana. Hukum pidana semacam ini tidak bertujuan melindungi masyarakat tetapi memperkuat alasan atau menentang perbuatan sewenang-wenang dari penguasa. jauh lagi kejahatan merupakan sebagian dari perbuatanperbuatan yang bertentangan dengan kesusilaan (Bonger,1982:19-20).

Sementara, kejahatan kesusilaan atau moral offences dari pelecehan seksual atau sexual harassment merupakan dua bentuk pelanggaran atas kesusilaan yang bukan saja merupakan masalah hukum nasional suatu negara, melainkan sudah merupakan masalah hukum semua negara di dunia atau merupakan masalah global (Atmasasmita, 1995: 103). Pertama adalah faktor yang berasal atau terdapat dalam diri si pelaku dengan maksud bahwa yang mempengaruhi seseorang untuk melakukan sebuah kejahatan itu timbul dari dalam diri si pelaku itu sendiri yang didasari oleh faktor keturunan dan kejiwaan (penyakit jiwa). Faktor yang kedua adalah faktor yang berasal atau terdapat di luar diri pribadi si pelaku maksudnya adalah yang mempengaruhi seseorang untuk melakukan suatu kejahatan itu timbul dari luar diri si pelaku itu sendiri yang di dasari oleh faktor rumah tangga, serta factor tehnologi dan lingkungan (Hamzah, 1986: 64).

\section{B. PERLINDUNGAN HUKUM TERHADAP ANAK KORBAN KEJAHATAN SEKSUAL}

\section{Pengertian Korban}

Pengertian korban seperti yang tercantum dalam Pasal 1 angka(2) Undang-Undang Nomor 13 Tahun 2006 tentang Perlindungan Saksi dan Korban menyatakan bahwa korban adalah seseorang yang mengalami penderitaan fisik, mental, atau kerugian ekonomi yang diakibatkan oleh suatu tindak pidana (Kurnia, 2005: 6-7). Korban suatu tindak pidana (kejahatan) seringkali dibuat kecewa oleh praktik-praktik penyelenggaraan hukum yang lebih condong memperhatikan dan bahkan melindungi hak-hak asasi tersangka, sedangkan hak-hak asasi korban lebih banyak diabaikan (Marzuki, 1995: 197).

\section{Bentuk-Bentuk Perlindungan Anak}

Masalah anak memang bukan suatu masalah kecil, akan tetapi anak adalah sebagai generasi penerus bangsa dan negara. Faktor yang mendukung pelayanan terhadap anak korban kejahatan, ini dipertegas lagi oleh Arif Gosita adalah sebagai berikut:

a. Keinginan untuk mengembangkan perlakuan adil terhadap anak dan peningkatan kesejahteraan anak.

b. Hukum kesejahteraan yang dapat mendukung pelaksanaan pelayanan terhadap anak korban kejahatan.

c. Sarana yang dapat dimanfaatkan untuk melaksanakan pelayanan terhadap anak 
korban kejahatan (Gosita, 241).

Oleh karena itu, merupakan kewajiban bagi generasi terdahulu untuk menjamin, memelihara, dan mengamankan kepentingan anak. Pemeliharaan, jaminan, dan pengamanan kepentingan tersebut selayaknya dilakukan oleh pihak-pihak yang mengasuhnya yaitu keluarga. Dilihat dari Teori Perlindungan Hukum, Perlindungan anak merupakan suatu usaha yang mengadakan situasi dan kondisi yang memungkinkan pelaksanaan hak dan kewajiban anak secara manusiawi.

Implementasi perlindungan hukum bagi anak sebagai korban ternyata belum maksimal sebagaimana yang diberikan oleh undangundang. Walaupun belum maksimal, namun ada beberapa bentuk perlindungan hukum yang sudah diberikan kepada anak sebagai korban sesuai Undang-Undang No. 35 Tahun 2014 yang terdapat pada Pasal 64 ayat (3), bahwa anak sebagai korban mendapatkan:

1. Rehabilitasi baik dalam lembaga maupun luar lembaga

2. Upaya perlindungan dan pemberitaan identitas melalui media massa untuk menghindari labelisasi

3. Pemberian jaminan keselamatan bagi saksi korban dan saksi ahli baik fisik, mental, maupun sosial

4. Pemberian aksebilitas untuk mendapatkan informasi mengenai perkembangan perkara (Yulia, 2010: 196).

\section{HUKUM PROGRESIF}

\section{Pengertian Hukum}

Dalam fungsinya, hukum sebagai perlindungan kepentingan manusia, hukum mempunyai tujuan. Hukum mempunyai sasaran yang hendak dicapai. Adapun tujuan pokok hukum untuk menciptakan tatanan masyarakat yang tertib, menciptakan ketertiban, dan keseimbangan. Dalam pengertian lain, hukum bertugas membagi hak dan kewajiban antar perorangan didalam masyarakat, membagi wewenang dan mengatur cara memecahkan masalah hukum serta memelihara kepastian hukum (Mas, 2004: 72).

Sistem Hukum tidak hanya mengacu pada aturan (codes of rules) dan peraturan (regulations), namun mencakup bidang yang luas, meliputi struktur, lembaga dari proses (procedure) yang mengisinya terkait dengan hukum yang hidup dalam masyarakat (living law), dan budaya hukum (legal structure). Menurut Lawrence M Friedman, unsur dari sistem hukum terdiri dari struktur hukum (legal structure), substansi hukum (legal substance) dan budaya hukum (legal culture).

Fungsi utama hukum yaitu mengatur ketertiban merupakan syarat dasar bagi adanya suatu masyarakat, kebutuhan akan ketertiban merupakan fakta dan kebutuhan objektif bagi setiap masyarakat manusia. Tujuan hukum adalah untuk mewujudkan keadilan. Hukum ada atau diadakan adalah untuk mengatur dan menciptakan keseimbangan atau harmonisasi kepentingan manusia, ketiga tujuan ini sering diungkapkan secara terpisah dan dianggap sebagai suatu proses yang saling menentukan satu sama lain, yaitu: kepastian, keteraturan, ketertiban, dan keadilan.

Keteraturan tidak mungkin terwujud tanpa kepastian dan orang tidak mungkin mempersoalkan keadilan dalam ketidakteraturan. Dalam fungsinya, hukum sebagai perlindungan kepentingan manusia, hukum mempunyai tujuan. Dalam pengertian lain, hukum bertugas membagi hak dan kewajiban antar perorangan didalam masyarakat, membagi wewenang dan mengatur cara memecahkan masalah hukum serta memelihara kepastian hokum (Mertokusumo, 1999: 71).

\section{Hukum Progresif}

Gagasan hukum progresif muncul karena prihatin terhadap kualitas penegakan hukum di 


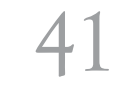

VOL. 23 N0.1 JUNI 2016

Indonesia terutama sejak terjadinya reformasi pertengahan tahun 1997. Jika fungsi hukum dimaksudkan untuk turut serta memecahkan persoalan kemasyarakatan secara ideal, maka yang dialami di Indonesia sekarang ini adalah sangat bertolak belakang dengan cita-cita ideal tersebut (Rahardjo, 2005: 3-5).

Berkaitan dengan hal tersebut, maka hukum tidak ada untuk dirinya sendiri, melainkan untuk sesuatu yang lebih luas dan lebih besar. Tetapi pada hakekatnya teori-teori hukum yang ada berakar pada kedua faktor tersebut.

Semakin landasan suatu teori bergeser ke faktor hukum, semakin suatu teori menganggap hukum sesuatu yang mutlak-otonom dan final. Semakin bergeser kemanusia, semakin teori tersebut ingin memberikan ruang kepada faktor manusia ((Rahardjo, 2005: 3-5).

\section{PERLINDUNGAN HUKUM TERHADAP ANAK KORBAN KEJAHATAN SEKSUAL MENURUT HUKUM POSITIF}

Perlindungan hukum terhadap anak merupakan upaya perlindungan berbagai kebebasan hak asasi anak (fundamental rights and freedom of children), serta berbagai kepentingan yang berhubungan dengan kesejahteraan anak. Perlindungan hukum bagi anak mencakup lingkup yang luas. Dalam perspektif kenegaraan, negara melindungi warga negaranya termasuk didalamnya terhadap anak dapat di temukan dalam pembukaan UndangUndang Dasar 1945 yang tercermin pada alinea Ke-IV, didalam penjabarannya BAB XA tentang Hak Asasi Manusia, khususnya untuk perlindungan terhadap anak, Pasal 28B ayat (2) UUD1945 dinyatakan bahwa setiap anak berhak atas kelangsungan hidup, tumbuh dan berkembang, serta berhak atas perlindungan dari kekerasan dan diskriminasi.

Perlindungan hukum adalah segala daya upaya yang dilakukan secara sadar oleh setiap orang maupun lembaga pemerintah, bahkan swasta yang bertujuan mengusahakan pengamanan, penguasaan, dan pemenuhan kesejahteraan hidup sesuai dengan hak-hak asasi yang ada (UU No. 39 Tahun 1999 tentang Hakhak Asasi Manusia).

Definisi mengenai pengertian anak dapat dilihat dari berbagai macam peraturan perundang-undangan sebagai berikut:

1. Kitab Undang-Undang Hukum Perdata (KUHPerdata)

Menurut KUHPerdata batas kedewasaan anak diatur dalam Buku I pada Pasal 330KUHPerdata yang menyatakan bahwa, belum dewasa adalah mereka yang belum mencapai umur genap dua puluh satu tahun, dan tidaklebih dahulu kawin.

2. Kitab Undang-Undang Hukum Pidana Didalam Pasal 45 KUHP disebutkan bahwa dalam menuntut anak yang belum cukup umur (minderjaring) karena melakukan perbuatan sebelum umur enam belas tahun, hakim dapat memutuskan sebagai berikut:

a. Memerintahkan supaya yang bersalah dikembalikan kepada orangtuanya, walinya atau pemeliharanya, tanpa dipidana apaupun.

b. Memerintahkan supaya yang bersalah diserahkan kepada pemerintah, tanpa dipidana apapun.

Selanjutnya pandangan hukum positif terhadap perlindungan anak korban kejahatan seksual dilihat dari:

1. UU No.13 Tahun 2006 tentang Perlindungan Saksi dan Korban.

Hak asasi manusia merupakan hak dasar, pemberian Tuhan yang dimiliki manusia selama hidup dan sesudahnya, serta tidak dapat dicabut dengan semau-maunya tanpa ketentuan hukum yang ada, jelas, dan benar. Selanjutnya, dipertegas lagi oleh Muladi alasan perlunya negara memberikan perlindungan terhadap korban individu maupun perlindungan bagi masyarakat harus berdasarkan argumen kontrak 
sosial dan argumen solidaritas social (Muchsin, 2007: 31). Guna mencapai tujuan tersebut, maka pelaksanaan perlindungan tidak boleh dipisahkan dari prinsip-prinsip dasar perlindungan anak dalam konvensi hak anak dan kebudayaan.

\section{E. KEDUDUKAN KORBAN TINDAK PIDANA SEKSUAL DALAM SISTEM PERADILAN PIDANA INDONESIA}

Peradilan pidana (the juvenile justice system) merupakan salah satu bentuk perlindungan yang diberikan hukum kepada anak yang telah melakukan tindak pidana. Orientasi dari keseluruhan proses peradilan pidana anak ini harus ditujukan pada kesejahteraan anak itu sendiri, dengan dilandasi prinsip kepentingan terbaik bagi anak (the best interest for children) bahwa adanya dua sasaran dibentuknya peradilan anak, yaitu:

1. Memajukan kesejahteraan anak (the promotion of the well being of the juvenile), berarti prinsip kesejahteraan anak ini harus dipandang sebagi fokus utama dalam sistem peradilan anak. Prinsip ini dapat dijadikan dasar untuk tidak menerapkan penggunaan sanksi yang semata-mata bersifat pidana, atau yang bersifat menghukum.

2. Mengedepankan prinsip proporsionalitas (the principle of proporsionality), merupakan sarana untuk mengekang penggunaan sanksi yang bersifat menghukum dalam arti membalas. Hal ini dipertegas Paul H. Hann mengemukakan pendapatnya bahwa pengadilan anak janganlah semata-mata sebagai suatu peradilan pidana bagi anak dan tidak pula harus berfungsi semata-mata sebagai suatu lembaga social (Muladi, 1992: 114).

Jaminan umum yang dimaksud tersebut adalah jaminan-jaminan yang bersifat prosedural yang paling mendasar, antara lain:

1. Hak untuk diberitahukannya tuduhan,
2. Hak untuk tetap diam,

3. Hak untuk memperoleh penasehat hukum,

4. Hak untuk hadirnya orang tua/wali,

5. Hak untuk menghadapkan saksi dan pemeriksaan silang para saksi

6. Hak untuk banding ke tingkat yang lebih tinggi.

\section{F. PENERAPAN DIVERSI DALAM PERSIDANGAN ANAK}

Dalam Pasal 5 ayat(1) menyatakan bahwa sistem peradilan pidana anak wajib mengutamakan pendekatan keadilan restoratif, keadilan restoratif yang dimaksud dalam Pasal 5 tersebut adalah kewajiban melaksanakan diversi. Diversi diartikan sebagai pengalihan. Hal ini dipertegas lagi oleh Romli Artasasmita bahwa diversi yaitu kemungkinan hakim menghentikan atau mengalihkan/tidak meneruskan pemeriksaan perkara dan pemeriksaan terhadap anak selama proses pemeriksaan dimuka siding (Wahyudi, 2011: 14).

\section{G. KENDALA PENERAPAN UNDANG- UNDANG PERLINDUNGAN ANAK}

Banyaknya kekurangan didalam peraturan Perundang- undangan yang secara terpisah mengatur tentang perlindungan saksi dan Korban yang seharusnya secara hukum banyak pihak yang dijadikan saksi engan untuk menjadi saksi. Hal ini karena merasa terancam jiwa dan keluarganya terhadap apa yang disampaikan, baik ditingkat penyidikan sampai di Pengadilan.

Bahkan yang semulanya menjadi saksi akan tetapi akhirnya ditetapkan sebagai tersangka.

Oleh karena itu, baik saksi korban dan pelapor dalam perkara anak mesti mendapatkan perlindungan dan bantuan hukum.

Implementasi Undang Undang Perlindungan Anak (UUPA) di Indonesia dirasa masih sangat sulit diberlakukan secara sungguh-sungguh dan masih menjadi kendala. Penyebabnya tidak lain 
dari banyaknya yang turut menjadi konsumen atau pengguna jasa pekerja seks anak.

Selanjutnya Satjipto Raharjo mendeskripsikan bahwa lemahnya penegakan hukum pada hakikatnya merupakan penegakan ide-ide atau konsep-konsep tentang keadilan, kebenaran, kemanfaatan sosial. Penegakan hukum merupakan usaha untuk mewujudkan ide dari konsep-konsep yang menjadi kenyataan. Penegakan hukum dan penggunaan hukum adalah dua hal yang berbeda. Seseorang dapat menegakkan hukum untuk memberikan keadilan, tetapi seseorang juga dapat menegakkan hukum untuk digunakan bagi pencapaian tujuan atau kepentingan lain, menegakkan hukum tidak persis sama dengan menggunakan hukum.

Menurut Black's Law Dictionary, penegakan hukum merupakan usaha untuk menegakkan norma-norma dari kaidah-kaidah hukum sekaligus nilai-nilai yang ada di belakangnya. aparat penegak hukum hendaknya memahami benar-benar jiwa hukum (legal spirit) yang mendasari peraturan hukum yang harus ditegakkan, terkait dengan berbagai dinamika yang terjadi dalam proses pembuatan perundang-undangan (law making process).

Mengingat kasus kekerasan pada anak biasanya lebih banyak terjadi pada anak dari kalangan bawah, sebagai contoh, pihak kepolisian umumnya akan malas menanganinya. Karenanya, kasus-kasus anak itu tidak bisa dijadikan lahan memperoleh uang. Sebaliknya, kalau pelaku kekerasan berasal dari golongan kaya, yang mampu membayar polisi, jaksa dan hakim, pelaku akan dibebaskan dengan mudah, dan layak (Hanafi, 1986: 255). Dalam konteks Negara Indonesia, keadilan yang hendak diwujudkan sesuai dengan yang tertuang dalam sila ke 3 Pancasila. Keadilan sosial bagi seluruh rakyat Indonesia. Dengan demikian, sistem tidak hanya untuk memidana pelaku tetapi mewujudkan keadilan bagi korban kejahatan dan memanusiakan manusia yang sesuai dengan tujuan hukum progresif.

\section{H. UNSUR-UNSUR DALAM PENEGAKAN HUKUM TERHADAP ANAK KORBAN KEJAHATAN SEKSUAL}

\section{Pengadilan}

Pengaturan mengenai badan pengadilan dalam sistem hukum dimasukkan ke dalam kategori kekuasaan kehakiman.Kekuasaan kehakiman adalah kekuasaan negara yang merdeka untuk menyelenggarakan peradilan, guna menegakkan hukum dan keadilan berdasarkan Pancasila demi terselenggaranya negara hukum. Lebih lanjut dalam penyelenggaraan kekuasaan kehakiman diserahkan kepada badan peradilan dengan tugas pokok untuk menerima, memeriksa, mengadili, serta menyelesaikan setiap perkara yang diajukan (Rahardjo, 2009: 12).

Tugas menyelenggarakan peradilan yang diperinci ke dalam kegiatan- kegiatan menerima, memeriksa, dan mengadili perkara. Pengadilan di dalam melakukan penegakan hukum, dengan cara mengadili seperti yang dikehendaki oleh sistim hukum yang termasuk ke dalam kategori ajudikatif, yaitu menentukan apa yang sesungguhnya merupakan isi suatu peraturan, kemudian menentukan apakah peraturan itu telah dilanggar (khususnya dalam perkara pidana) (Rahardjo, 2009: 12).

\section{Polisi}

Di antara pekerjaan-pekerjaan penegakan hukum, pekerjaan kepolisian adalah yang paling menarik. Hal tersebut menjadi menarik, karena di dalamnya banyak dijumpai keterlibatan manusia sebagai pengambil keputusan. Polisi pada hakekatnya dapat dilihat sebagai hukum yang hidup, karena di tangan polisi tersebut hukum mengalami perwujudannya, setidaktidaknya di bidang hukum pidana.

\section{FAKTOR-FAKTOR YANG}




\section{MEMPENGARUHI PENEGAKAN HUKUM DALAM PERLINDUNGAN TERHADAP ANAK KORBAN KEJAHATAN SEKSUAL DI SUMATERA UTARA}

Faktor-faktor yang dapat mempengaruhi penegakan hukum tersebut, antara lain:

1. Faktor Hukum.

Pada faktor hukum, dalam hal kaitannya dengan undang-undang yang berlaku di Indonesia, undang undang semakin beragam bentuk serta tujuannya dan hampir dalam kehidupan sehari-sehari masyarakat harus menaati peraturan tersebut. Semua penegak hukum mau berbuat demikian.

2. Faktor Sarana Atau Fasilitas Masalah peranan dianggap penting karena penegak hukum lebih banyak tertuju pada diskresi. Didalam penegakan hukum diskresi sangat penting karena:

a. Tidak ada perundang-undangan yang sedemikian lengkap, sehingga dapat mengatur semua perilaku manusia.

b. Adanya kelambatan-kelambatan untuk menyesuaikan perundang-undangan dengan perkembangan-perkembangan di dalam masyarakat, sehingga menimbulkan ketidak pastian.

c. Kurangnya biaya untuk menerapkan perundang-undangan sebagaimana yang dikehendaki oleh pembentuk undangundang.

d. Adanya kasus-kasu individual yang memerlukan penanganan secara khusus.

Sarana atau fasilitas di bidang hukum harus benar-benar berjalan secara baik karena sarana atau fasilitas tersebut menjadi sebuah dukungan demi kelancaran penegakan hukum di Sumut. Sarana atau fasilitas yang dimaksud mencakup mengenai proses perkara pidananya.

Sumatera Utara merupakan daerah titik rawan akan tindak kejahatan terhadap anak. Hal ini terlihat dari data yang ada pada kasus pengaduan pada Komisi Perlindungan Anak
Indonesia Daerah Sumatera Utara. Di asumsikan per tiga bulan, ada 13 kasus pencabulan yang terjadi di Sumut. Sehingga ada lonjakan kenaikan sekitar $100 \%$ pada tri semester pertama pada tahun 2012. Kasus penganiayaan berjumlah 22 kasus, sodomi 9 kasus, pemerkosaan 8 kasus, Hak Kuasa Asuh (HKA) 55 Kasus, penelantaran 22 kasus, anak berhadapan dengan hukum 14 kasus, hak pendidikan anak 7 kasus, trafficking 7 kasus dan, lainnya yang berjumlah keseluruhan untuk Tahun 2012 berjumlah 192 kasus Tahun 2013 jumlahnya meningkat menjadi 199 kasus. Korban kekerasan seksual ada 53 kasus adalah anak laki-laki, dengan perbandingan persentase 60 persen anak laki laki dan 40 persen anak perempuan.

Adapun profil pelaku di hampir semua kasus sama, yakni orang-orang terdekat anak. Pelaku adalah guru, om, ayah kandung, ayah tiri, dan tetangga. Tapi pada Tahun 2014 sejak Januari sampai Maret, anak yang menjadi korban ada 244 kasus, korban kekerasan seksual 53 kasus dan lainnya 191 kasus. Sumatera Utara, khususnya Medan, termasuk dalam kondisi darurat kejahatan seksual terhadap anak, sepanjang tahun 2013 oleh Kelompok Kerja (Pokja) Perlindungan Anak Sumut. Kota Medan mencatat terdapat 12.679 kasus pelanggaran hak anak yang tersebar di 23 kabupaten/kota.Hal itu diungkapkan oleh Ketua Umum Komnas Perlindungan Anak, Aris Merdeka Sirait, bahwa, sebanyak 52 persen atau setara 7.335 kasus dari pelanggaran tersebut adalah kejahatan seksual terhadap anak. Sedangkan sisanya merupakan kasus kekerasan fisik, penelantaran dan eksploitasi ekonomi, perdagangan anak untuk tujuan eksploitasi seksual komersial, serta kasuskasus perebutan anak (Sirait, SUMUTPOS, 155-2014).

Hal ini dilakukan oleh Pemerintah Provinsi Sumatera Utara dalam melindungi anak dengan mengeluarkan beberapa kebijakan antara lain: 
1. Perda No. 5 Tahun 2004 tentang BentukBentuk Pekerjaan Terbaik Bagi Anak

2. Perda No. 6 Tahun 2004 tentang Pencegahan Perdagangan Orang (Tafiking)

3. Perda No. 8 Tahun 2008 tentang Gelandangan dan Pengemis (Gepeng) 4. Perda No. 3 Tahun 2014 Tentang

Penyelenggaraan Perlindungan Anak.

Setiap tahun kekerasan terhadap anak selalu meningkat. Data Komisi Nasional Perlindungan Anak (KNPA) dalam tiga tahun terakhir menunjukkan data yang terus meningkat, yaitu tahun 2012 terdapat 1.383 kasus, tahun 2013 tercatat 2.792 kasus dan per-April 2014 jumlah pengaduan telah mencapai jumlah 3.023 kasus. Dari jumlah tersebut, menurut jenisnya, kekerasan seksual merupakan salah satu jenis kekerasan yang mendominasi terjadi pada anakanak.

Data Komisi Perlindungan Anak Indonesia (KPAI) mencatat kekerasan seksual terhadap anak dari 2012 sampai 2013 meningkat sebesar 30 persen dan selama tiga tahun terakhir, ratarata lebih dari 45 anak mengalami kekerasan seksual setiap bulannya. Jenis kekerasan seksual yang dialami anak yang paling banyak terjadi dalam bentuk sodomi, pemerkosaan, pencabulan, serta inses. Kasus terbaru terjadi di Jakarta Selatan (DKI Jakarta), Depok dan Sukabumi (Jawa Barat), Tangerang (Banten), Pelalawan (Pekanbaru), Aceh Tenggara, Nagan Raya Aceh, dan Banda Aceh (DI Aceh), Padang (Sumatera Barat), Medan (Sumatera Utara), dan Kutai Kartanegara (Kalimantan Timur).

Pemberitaan ini diyakini hanyalah segelintir dari kekerasan seksual terhadap anak yang merupakan fenomena gunung es. Para korban kekerasan seksual anak tidak hanya mengalami kelukaan fisik, kerusakan organ tubuh dan seksualitasnya, serta terjangkiti penyakit infeksi menular seksual. Perhatian itu harus diwujudkan melalui kebijakan kongkrit dan strategis, antara lain:
1. Menetapkan tahun 2014 sebagai tahun Darurat Nasional Perlindungan Anak dari Kejahatan Seksual. Status darurat nasional ini diwujudkan dalam bentuk memberikan perhatian secara nasional di seluruh kawasan negara Republik Indonesia agar seluruh level pemerintah memberikan perhatian serius dalam penanganan kekerasan terhadap anak, khususnya kekerasan seksual.

2. Mewajibkan lembaga-lembaga perlindungan dan penegakan hukum untuk memprioritaskan kasus-kasus kekerasan terhadap anak, menjamin perlindungan dalam penanganannya, dan memastikan penanganan dampak yang dialami korban dan keluarga korban dilakukan secara tepat dan maksimal hingga hasil yang terbaik.

3. Menetapkan kekerasan seksual pada anak sebagai pelanggaran HAM berat dan merevisi batas maksimal hukuman pidana bagi pelaku kekerasan seksual pada anak menjadi hukuman seumur hidup.

4. Memastikan penegakan hukum (law enforcement) yang memenuhi rasa keadilan korban, keluarga korban, dan masyarakat, serta menjatuhkan hukuman yang maksimal terhadap pelaku kekerasaan seksual terhadap anak.

Hukum progresif bertumpu pada manusia membawa konsekuensi pentingnya kreativitas. Kreativitas dalam konteks penegakan hukum selain untuk mengatasi ketertinggalan hukum, mengatasi ketimpangan hukum, juga dimaksudkan untuk membuat terobosanterobosan hukum. Terobosan-terobosan hukum inilah yang dapat diharapkan dapat mewujudkan tujuan kemanusiaan melalui bekerjanya hukum, untuk membuat kebahagian manusia. Secara teoritik hukum dibagi menjadi dua, hukum bermakna obyektif dan hukum bermakna subyektif. Hukum obyektif ialah peraturan-peraturan yang mengatur hubungan antara sesama bermasyarakat, sedangkan hukum 
subyektif ialah kewenangan atau hak yang diperoleh seseorang berdasarkan hukum obyektif. Sedangkan progresif bermakna maju, berhasrat maju dan selalu maju. Dari dua term tersebut dapat dikatakan bahwa hukum progresif ialah peraturan-peraturan yang mengatur hubungan antara sesama masyarakat yang dibuat oleh seseorang atau kelompok yang mempunyai kewenangan membuat hukum dengan landasan keinginan untuk terus maju.

Satjipto Rahardjo memaknai hukum progresif dengan kalimat, pertama, hukum adalah untuk manusia dan bukan sebaliknya. Hukum tidak ada untuk dirinya melainkan untuk sesuatu yang luas, yaitu untuk harga diri manusia, kebahagiaan, kesejahteraan dan kemuliaan manusia. Kedua, hukum bukan merupakan institusi yang mutlak serta final, karena hukum selalu berada dalam proses untuk terus menjadi (law as a procces, law in making).

Hukum adalah untuk rakyat bukan sebaliknya. Bila rakyat adalah untuk hukum, apapun yang dipikirkan dan dirasakan rakyat akan ditepis karena yang dibaca adalah kata-kata Undang-Undang. Seorang hakim bukan hanya teknisi Undang-Undang tetapi juga makhluk sosial. Pekerjaan hakim sungguh mulia, karena ia bukan hanya memeras otak tapi juga nuraninya. Sehingga eksistensi hukum progresif bertolak dari dua komponen basis dalam hukum, yaitu peraturan dan prilaku (rules and behavior). Hukum ditempatkan sebagai aspek prilaku namun juga sekaligus sebagai peraturan. Peraturan akan membangun suatu sistem hukum positif, sedangkan prilaku atau manusia akan menggerakkan peraturan dan sistem yang telah (akan) terbangun.

Hukum progresif sebagaimana telah diungkap di atas, menghendaki kembalinya pemikiran hukum pada falsafah dasarnya yaitu hukum untuk manusia. Manusia menjadi penentu dan titik orientasi dari keberadaan hukum. Karena itu, hukum tidak boleh menjadi institusi yang lepas dari kepentingan pengabdian untuk mensejahterakan manusia. Para pelaku hukum dituntut untuk mengedepankan kejujuran dan ketulusan dalam penegakan hukum. Mereka harus memiliki empati dan kepudian pada penderitaan yang dialami oleh rakyat dan bangsanya. Kepentingan rakyat baik kesejahteran dan kebahagiannya harus menjadi titik orientasi dan tujuan akhir dari penyelenggaraan hukum. Dalam konteks ini, term hukum progresif nyata menganut ideologi hukum yang pro keadilan dan hukum yang pro rakyat.

Sebagai suatu sistem, budaya berkenaan atau bersangkutan dengan kompleksitas hayatan, renungan, gagasan, pikiran, pandangan dan nilai yang pada hakikatnya merupakan ekspresi dan eksternalisasi kegiatan budi manusia dalam menjalani, mempertahankan serta mengembangkan hidup dan kehidupan manusia (Kleden, 1987: 155). Pemerintah Kabupaten Tapanuli Selatan Propinsi Sumatera Utara dengan kebiasaan Dalihan na tolunya yang mempunyai pengaruh adat yang sangat besar sebab belum mempercayai dengan secara penuh tentang adanya hukum yang berlaku di negara ini.

\section{PENUTUP}

\section{A. SIMPULAN}

1. Konsep perlindungan hukum terhadap anak korban kejahatan seksual menurut hukum positif adalah harus berdasarkan Pancasila dalam memberikan perlindungan hukum terhadap warga masyarakatnya. Karena itu, perlindungan hukum tersebut akan melahirkan pengakuan dan perlindungan hak asasi manusia dalam wujudnya sebagai makhluk individu dan makhluk sosial, dalam wadah negara kesatuan yang menjunjung tinggi semangat kekeluargaan demi tercapainya kesejahteraan masyarakat

2. Penegakan hukum terhadap anak korban 
kejahatan seksual di Sumatera Utara secara konsepsional belum menyerasikan hubungan nilai-nilai yang terjabarkan didalam kaidahkaidah yang bagus dan mengejawantah sikap tindak sehingga masih ada sifat yang tidak sesuai dengan norma-norma hukum.

3. Pembangunan hukum terhadap perlindungan anak korban kejahatan seksual dalam perspektif hukum progresif bahwa Para pelaku hukum dituntut mengedepankan kejujuran dan ketulusan dalam penegakan hukum. Mereka harus memiliki empati dan kepedulian pada penderitaan yang dialami rakyat dari bangsa ini. Kepentingan rakyat (kesejahteraan dan kebahagiaannya) harus menjadi titik orientasi dan tujuan akhir penyelenggaraan hukum.

\section{B. SARAN}

1. Perlu memperhatikan konvensi Hak-hak Anak (KHA) dan aturan hukum lainnya sebagai dasar kebijakan pembangunan Indonesia, dengan tujuan memperkuat peran dan tanggung jawab negara terhadap kualitas hidup anak.

2. Penegakan hukum negara melalui pemerintah propinsi Sumatera Utara diharuskan menyiapkan wadah dan fasilitas dengan mengakui dan megefektifkan kearipan lokal melalui Dalihan na Tolu dalam memberikan perlindungan terhadap anak korban kejahatan seksual.

3. Dalam pembangunan hukum progresif telah dinyatakan bahwa setiap instansi yang tugas dan fungsinya untuk pelayanan terhadap masyarakat, khususnya yang dengan kualitas pelayanan tersebut berdampak pada kesejahteraan anak, harus melaksanakan tugas dan fungsinya secara optimal.

\section{DAFTAR PUSTAKA}

Buku

Ali, Ahmad, 2012, Menjelajai Kajian Empiris Terhadap hukum, Kencana Prenada Media Group, Jakarta Sugandhi 1981, KUHP dan Penjelasan, Usaha Nasional, Surabaya
Prasetyo, Teguh, 2013, Filsafat, Teori dan IImu Hukum, Pemikiran Menuju Masyarakat Yang Berkeadilan dan Bermartabat, PT. Raja Grafindo Persada, Jakarta

Marlina, 2010, Pengantar Konsep Diversi dan Restorative Justice Dalam Hukum Pidana, USU Press, Medan

Satjipto Rahardjo, 2006, Membedah Hukum Progresif, Kompas, Jakarta.

,2006, Sisi-sisi Lain dari Hukum di Indonesia, Cetakan Kedua, Buku Kompas, Jakarta

Black Henry Campbell, 1999, Black's Law Dictoopnry, Edisi VI, St. Paul Minesota West Publshing

Muladi, 2002, Hak Asasi Manusia: Politik dan Sistem Peradilan Pidana, Cetakan Kedua, Semarang, Badan Penerbit Universitas Diponegoro

Arif Gosita, 1996, Masalah Perlindungan Anak, Akademika Pressindo, Jakarta

Rena Yulia, 2010.Viktimologi Perlindungan Hukum Terhadap Korban Kejahatan, Graha Ilmu Bandung

Lawrance M.Friedman, 1984, American Law London, W.W. Norton \& Company

Mochtar Kusumaatmadja, 1986, Fungsi dan Perkembangan Hukum Dalam Pembangunan Nasional, Bina Cipta Bandung

Lili Rasjidi, 2003 Hukum Sebagai Suatu Sistem, Bandung, Mandar Maju Hukum, PT RajaGrafindo Persada, Jakarta

B. Simanjuntak, 1981, Dasar-Dasar Psychologi Kriminal, Tarsito Bandung.

Utrecht, 1986, Hukum Pidana I, Pustaka Tinta Mas, Surabaya

Wirjono Prodjodikoro, 2003, Asas-asas Hukum Pidana di Indonesia, Refika Aditama, Bandung

W.A.Bonger, 1982, Pengantar Tentang Kriminologi, PT. Pembangunan

Romli Atmasasmita, 1995, Kapita Selekta Hukum Pidana dan Kriminologi, Mandar Maju, Bandung

Andi Hamzah, 1986, Hukum Pidana dan Acara Pidana, Jakarta: Ghalia Indonesia

Titon Slamet Kurnia, 2005, Reparasi Terhadap Korban Pelanggaran HAM di Indonesia, Bandung, Citra Aditya Bakti,

Suparman Marzuki, 1995, Pelecehan Seksual, Fakultas Hukum UII, Yogyakarta

Marwan Mas, 2004, Pengantar Ilmu Hukum, Ghalia Indonesia, Jakarta 